\title{
Yield and yield components of Arachis hypogaea L. as influenced by NPK chemical fertilizers, farm yard manure and gypsum
}

\author{
Thayamini H. Seran*
}

Department of Crop Science, Faculty of Agriculture, Eastern University, Chenkalady, Sri Lanka.

\begin{abstract}
Field trials were conducted to evaluate the effect of chemical fertilizers, farmyard manure (FYM) and gypsum on yield and yield components of groundnut (Arachis hypogea L.). There were nine treatments included unfertilized treatment and full doses of recommended NPK fertilizers (65:100:75 kg/ha) or reduced doses of recommended NPK fertilizers (30:50:37.5 kg/ha) and FYM@10 t/ha in combination with different levels $(0,150,300$ and $450 \mathrm{~kg} / \mathrm{ha})$ of gypsum. The results exhibited that full dose of NPK fertilizers with $300 \mathrm{~kg} / \mathrm{ha}$ gypsum treatment gave significantly $(\mathrm{P}<0.05)$ higher seed yield $(2777.28 \mathrm{~kg} / \mathrm{ha})$ than the full dose of NPK fertilizers alone (typical control) which had $2276.05 \mathrm{~kg} / \mathrm{ha}$. On the other hand, application of reduced dose of NPK fertilizers $+10 \mathrm{t} / \mathrm{ha} \mathrm{FYM} \mathrm{with} 450 \mathrm{~kg} / \mathrm{ha}$ gypsum resulted 2609.88 $\mathrm{kg} / \mathrm{ha}$ seed yield followed by $300 \mathrm{~kg} / \mathrm{ha}$ gypsum application which had $2521.98 \mathrm{~kg} / \mathrm{ha}$ and both values were statistically similar. Thus, use of $300 \mathrm{~kg}$ /ha gypsum could give high seed yield of groundnut with full dose of NPK fertilizers alone or reduced dose of NPK fertilizers and 10 t/ha FYM. However, combined application of organic and inorganic fertilizers is better practice especially on sandy regosol when considering human and soil health.
\end{abstract}

Keywords: Groundnut, Gypsum; Farm yard manure; NPK chemical fertilizers; Seed yield

\section{Introduction}

Groundnut (Arachis hypogaea L.) is one of the valuable vegetable oil crops and its seeds contain high amount of edible oil (47\%) and protein (38\%) (Atasie et al., 2009). As a result, it is used for human consumption. Groundnut cake and haulms are also used as animal feed and organic manure (Ahmad and Rahim, 2007; Shah et al., 2012). In Sri Lanka, the cultivated extent and production of groundnut were 11609 ha and $21953 \mathrm{mt}$ respectively in 2012 according to the Department of Agriculture, Sri Lanka. It is grown mainly in dry and intermediate zones of Sri Lanka. Groundnut being leguminous crop has the ability to fix atmospheric nitrogen with the help of Rhizobium bacteria being living within the root nodules of legume crop and generally it contributes about $25 \mathrm{~kg} / \mathrm{ha}$ nitrogen (Veeramani and Subrahmaniyan, 2011). In usual agriculture, most of the farmers apply inadequate and imbalanced mineral nutrients which may cause for low groundnut productivity (Compaore et al., 2011) especially on sandy soil. Therefore, proper nutrient management is a crucial way to obtain optimal yield with good quality in vegetable oil seed crop.

Groundnut farmers mostly apply NPK nutrients to increase yield. However, nowadays various ways are being practiced to overwhelm problems encountered by using chemical fertilizers alone. When concerning cost of commercial chemical fertilizers as well as human and soil health, locally available organic manure can be used to enhance soil fertility and crop productivity (Hamza and Abd-Elhady, 2010; Mokhtariniya and Siadat, 2011) in developing countries. Addition of organic manures to soil also improves soil physical properties (Busscher et al., 2010) and penetration resistance in loam soils (Alvarez et al., 2009). Moreover, it contains both macro and micro nutrients. Oilseeds require high amounts of both macro and micro nutrients because they are energy-rich crops (Veeramani and Subrahmaniyan, 2011). Groundnut plants need high level of calcium during pod filling stage to obtain better yield of quality kernels and its deficiency directs to unfilled pods (Reddy, 2006). Gypsum is readily available source of calcium as well as sulfur for crops and sulfur is necessary for improving the oil content in groundnut (Rao et al., 2013). Hence, this experiment was done to study the effect of combined use of chemical fertilizers, farmyard manure (FYM) and gypsum on yield and yield components of groundnut.

\footnotetext{
*Corresponding author. e-mail: thayaminis@esn.ac.lk, thayaseran@yahoo.com
} 


\section{Materials and methods}

The experiment was conducted under rain fed conditions from 2012 - 2013 to find out the effect of combined use of chemical fertilizers, farm yard manure (FYM) and gypsum on yield and yield components of groundnut at the experimental station of the eastern region in Sri Lanka, which is located at $7^{\circ} 43^{\prime} \mathrm{N}$ and $81^{\circ} 42^{\prime} \mathrm{E}$. The mean rainfall ranged from $80-300 \mathrm{~mm}$ during the growing season of groundnut. The average minimum and maximum temperatures were $24^{\circ} \mathrm{C}$ and $31^{\circ} \mathrm{C}$, respectively and the average relative humidity ranged from $73 \%-85 \%$.

\section{Soil and manure analysis}

The type of soil at the experimental site was sandy regosol. Before planting, soil samples at a depth of 0-20 cm were collected to determine some properties of soil. The field soil has $6.4 \mathrm{pH}, 26.2 \mu \mathrm{S} / \mathrm{cm}$ electric conductivity, $0.35 \%$ organic matter, $6.6 \mu \mathrm{g} / \mathrm{g}$ nitrogen, $0.06 \mathrm{meq} / 100 \mathrm{~g}$ potash, $37.2 \mu \mathrm{g} / \mathrm{g}$ phosphate, $1.7 \mathrm{meq} / 100 \mathrm{~g}$ calcium and $6.5 \mu \mathrm{g} / \mathrm{g}$ sulfate. Similarly some chemical compositions of air dried farm yard manure applied were determined. It contained $1.11 \% \mathrm{~N}, 0.80$ $\% \mathrm{~K}_{2} \mathrm{O}, 0.12 \% \mathrm{P}_{2} \mathrm{O}_{5}$ and $0.41 \% \mathrm{Ca}$. Analysis was carried out on dry basis except $\mathrm{pH}$ and electric conductivity.

\section{Experimental design}

The experiment was laid out in a randomized complete block design with three replications. There were nine treatments including absolute and typical controls as given in Table I. Plot size was $4.86 \mathrm{~m}^{2}$.

\section{Table I. Treatments used in this experiment}

\begin{tabular}{lccc}
\hline \multirow{2}{*}{$\begin{array}{l}\text { Treatment } \\
\text { code }\end{array}$} & \multicolumn{3}{c}{ Total nutrients applied to soil } \\
\cline { 2 - 4 } & $\begin{array}{c}\text { NPK chemical } \\
\text { fertilizers } \\
\text { (Urea: TSP:MOP) } \\
\text { (kg/ha) }\end{array}$ & $\begin{array}{c}\text { Farm yard } \\
\text { manure } \\
(\mathrm{t} / \mathrm{ha})\end{array}$ & $\begin{array}{c}\text { Gypsum } \\
(\mathrm{kg} / \mathrm{ha})\end{array}$ \\
\hline T1 (absolute control) & $00: 00: 00$ & 0 & 0 \\
T2 (typical control*) & $65: 100: 75$ & 0 & 0 \\
T3 & $65: 100: 75$ & 0 & 150 \\
T4 & $65: 100: 75$ & 0 & 300 \\
T5 & $65: 100: 75$ & 0 & 450 \\
T6 & $30: 50: 37.5$ & 10 & 0 \\
T7 & $30: 50: 37.5$ & 10 & 150 \\
T8 & $30: 50: 37.5$ & 10 & 300 \\
T9 & $30: 50: 37.5$ & 10 & 450 \\
\hline
\end{tabular}

*Typical control ie chemical fertilizers applied as recommended by the Department of Agriculture, Sri Lanka.

\section{Agronomic practices}

Groundnut seeds cv. Indi were obtained from the Seed production and Processing unit at the Eastern University of Sri Lanka and one seed per hill was planted at a spacing of $45 \times$ $15 \mathrm{~cm}$. Full doses of recommended NPK fertilizers (Urea:TSP:MOP@35:100:75 kg/ha) or half doses of recommended PK fertilizers (TSP:MOP@50:37.5 kg/ha) with FYM@10 t/ha were uniformly applied as basal dressing while all experimental plots except absolute control (no fertilizer application at any stage) were treated with urea@30 $\mathrm{kg} / \mathrm{ha}$ and different levels $(0,150,300$ and $450 \mathrm{~kg} / \mathrm{ha})$ of gypsum as topdressing at flowering stage. Urea, TSP and MOP contain $46 \% \mathrm{~N}, 45 \% \mathrm{P}_{2} \mathrm{O}_{5}$ and $60 \% \mathrm{~K}_{2} \mathrm{O}$ respectively whereas gypsum consists of $22 \% \mathrm{Ca}$ and $17 \% \mathrm{~S}$. FYM were applied two weeks before planting and it was thoroughly mixed with the soil. Weeding was done manually and plants were irrigated with ground water to sustain the field capacity. Irrigation was stopped two weeks before harvesting.

\section{Data collection}

The randomly selected ten plants from each experimental plot were uprooted at 110 days after planting and the plants were separated into pods, shoot and roots. Numbers of pods and seeds per plant were counted. Subsequently, they were dried under sunlight for three days to record constant dry weights. Dry weights (g) of pods, seeds, shoot and roots per plant were measured and 100 seed weight (g) was taken. Shelling (\%), pod yield ( $\mathrm{t} / \mathrm{ha})$, seed yield $(\mathrm{t} / \mathrm{ha})$, and harvest index (HI) were calculated.

\section{Statistical analysis}

The collected data were subjected to analysis of variance using statistical analysis system software (SAS Institute, Cary, North Carolina, USA). Treatment mean separations were done using the Tukey's honesty significant difference test at 5\% significant level.

\section{Results and discussion}

Pod and seed numbers

There was a significant difference $(\mathrm{P}<0.01)$ in an average number of pods per plant among the treatments (Table II). It was remarkably lower value (10.67) in unfertilized treatment ie absolute control (T1) than treated plants. This is in line with finding of Munda et al. (2004), who reported that num 
Table II. The numbers and weights of pods and seeds per groundnut plant in each treatment.

\begin{tabular}{lcccc}
\hline Treatments & $\begin{array}{c}\text { Pod number } \\
\text { per plant }\end{array}$ & $\begin{array}{c}\text { Seed number per } \\
\text { plant }\end{array}$ & $\begin{array}{c}\text { Air dried pod weight } \\
(\mathrm{g}) \text { per plant }\end{array}$ & $\begin{array}{c}\text { Air dried seed weight } \\
(\mathrm{g}) \text { per plant }\end{array}$ \\
\hline T1 & $10.67 \pm 0.33^{\mathrm{b}}$ & $16.00 \pm 0.50^{\mathrm{d}}$ & $11.47 \pm 0.48^{\mathrm{c}}$ & $05.91 \pm 0.35^{\mathrm{d}}$ \\
T2 & $21.83 \pm 0.88^{\mathrm{a}}$ & $29.00 \pm 0.29^{\mathrm{c}}$ & $23.97 \pm 0.67^{\mathrm{b}}$ & $15.36 \pm 0.29^{\mathrm{bc}}$ \\
T3 & $23.00 \pm 0.29^{\mathrm{a}}$ & $31.83 \pm 1.09^{\mathrm{bc}}$ & $25.72 \pm 1.12^{\mathrm{ab}}$ & $16.88 \pm 0.55^{\mathrm{abc}}$ \\
T4 & $25.00 \pm 1.04^{\mathrm{a}}$ & $32.00 \pm 0.29 \mathrm{bc}$ & $28.38 \pm 0.41^{\mathrm{a}}$ & $18.72 \pm 0.34^{\mathrm{a}}$ \\
T5 & $24.67 \pm 0.17^{\mathrm{a}}$ & $31.17 \pm 1.30^{\mathrm{bc}}$ & $27.32 \pm 1.30^{\mathrm{ab}}$ & $17.80 \pm 0.67^{\mathrm{ab}}$ \\
T6 & $22.00 \pm 0.76^{\mathrm{a}}$ & $32.67 \pm 0.88^{\mathrm{abc}}$ & $23.12 \pm 1.23^{\mathrm{b}}$ & $14.98 \pm 0.42^{\mathrm{c}}$ \\
T7 & $22.67 \pm 0.44^{\mathrm{a}}$ & $35.17 \pm 1.09^{\mathrm{ab}}$ & $25.03 \pm 1.14^{\mathrm{ab}}$ & $16.29 \pm 0.85^{\mathrm{abc}}$ \\
T8 & $24.67 \pm 0.73^{\mathrm{a}}$ & $36.67 \pm 0.88^{\mathrm{a}}$ & $26.37 \pm 0.56^{\mathrm{ab}}$ & $17.02 \pm 0.53^{\mathrm{abc}}$ \\
T9 & $25.00 \pm 0.58^{\mathrm{a}}$ & $32.83 \pm 1.01^{\mathrm{abc}}$ & $27.21 \pm 0.40^{\mathrm{ab}}$ & $17.62 \pm 0.47^{\mathrm{ab}}$ \\
F test & $* *$ & $* *$ & $* *$ & $* *$ \\
CV $\%$ & 5.28 & 4.85 & 5.98 & 5.46 \\
\hline
\end{tabular}

Values are means \pm standard error of three replications. Means followed by the same letter are not significantly different from each other at 5\% significant level according to Tukey's honestly significant difference test at 5\% significant level.

ber of pods per groundnut plant was increased by 20:60:40 $\mathrm{kg} /$ ha $\mathrm{N}: \mathrm{P}_{2} \mathrm{O}_{5}: \mathrm{K}_{2} \mathrm{O}$ application as compared to control. In the present study, the number of pods was affected by the gypsum application $(0-450 \mathrm{~kg} / \mathrm{ha})$ however it was statistically similar $(\mathrm{P}>0.05)$ among the treated plants and ranged from 21.83 to 25.00 . The highest average number (36.67) of seeds per plant was obtained from NPK fertilizers + FYM +300 $\mathrm{kg} / \mathrm{ha}$ gypsum (T8) and also the effect of T8 was considerably $(\mathrm{P}<0.05)$ high as compared to the result of either NPK fertilizers alone (T2 as typical control) or NPK fertilizers with gypsum (T3-T5). The average number of seeds per plant was 29.00 in T2 while T4 and T5 had 32.00 and 31.17 respectively.

\section{Pod and seed weights}

The mean weight of pods per plant was significantly affected $(\mathrm{P}<0.01)$ by nutrients applied to the plants (Table II). There was noticeable variation $(\mathrm{P}<0.05)$ in pod weight between gypsum treated and untreated plants. Significantly highest pod weight (28.38 g) was recorded with NPK fertilizers and $300 \mathrm{~kg} / \mathrm{ha}$ gypsum (T4) which, remarkably differed from T1, T2 and T6 but the other treatments were statistically similar with T4. This is proved by the result which showed increase in pod weight by gypsum application. In term of mean seed weight, there was a significant difference $(\mathrm{P}<0.05)$ between unfertilized and fertilized treatments. Seed weight ranged from $14.98 \mathrm{~g}$ (T6) to $18.72 \mathrm{~g}$ (T4) among the fertilized treatments. Treatment T9 (with gypsum) had remarkable effect $(\mathrm{P}<0.05)$ on seed weight than T6 (without gypsum). It was $17.62 \mathrm{~g}$ in T9 while T6 had $14.98 \mathrm{~g}$. The weights of pods and seeds per plant tended to increase about $18 \%$ and $22 \%$ respectively with higher dose of gypsum ie $300 \mathrm{~kg} /$ ha gypsum (T4) in NPK fertilizers + gypsum treatments. It had significantly $(\mathrm{P}<0.05)$ higher values than typical control (NPK fertilizers alone). Application of gypsum at $250 \mathrm{~kg} / \mathrm{ha}$ enhanced the pod yield of groundnut than control ie without gypsum treatment (Rao and Shaktawat, 2005; Thilakarathna et al., 2014).

\section{0 seed weight}

The average one hundred seed weight was statistically similar $(\mathrm{P}>0.05)$ among the treatments except T1 (Table III). Application of gypsum at 150 or $300 \mathrm{~kg} /$ ha slightly increased the one hundred seed weight over control (T2) and the highest seed weight was obtained at $300 \mathrm{~kg} / \mathrm{ha}$ gypsum application. The lowest weight was recorded in T1 which had an average of $43.77 \mathrm{~g}$. The one hundred seed weight ranged from 51.17 - $53.42 \mathrm{~g}$ among the treated plants.

\section{Shelling percentage}

The average shelling \% exhibited a significant difference $(\mathrm{P}<0.01)$ among the treatments (Table III) however remarkable variations $(\mathrm{P}>0.05)$ were not noted by the gypsum treatments. The lowest shelling \% was recorded in absolute control (T1) which had 51.5\% and it was significant from other treatments. Among the fertilizers treated plants, high shelling percentage was in T4 $(66.05 \%)$ and low in T2 (64.13\%) i.e., in typical control. Certain amount of gypsum 
Table III. The 100 seed weight, shelling \%, crop residue weight and plant biomass of groundnut in each treatment

\begin{tabular}{lcccc}
\hline Treatments & 100 seed weight $(\mathrm{g})$ & Shelling $\%$ & Crop residue $(\mathrm{g})$ per plant & Biomass $(\mathrm{g})$ per plant \\
\hline T1 & $43.77 \pm 0.71^{\mathrm{b}}$ & $51.50 \pm 1.05^{\mathrm{b}}$ & $14.22 \pm 0.73^{\mathrm{b}}$ & $25.68 \pm 1.21 \mathrm{c}$ \\
T2 & $52.03 \pm 0.61^{\mathrm{a}}$ & $64.13 \pm 0.62^{\mathrm{a}}$ & $19.83 \pm 1.03^{\mathrm{a}}$ & $43.80 \pm 1.14^{\mathrm{b}}$ \\
T3 & $53.35 \pm 0.71^{\mathrm{a}}$ & $65.72 \pm 1.02^{\mathrm{a}}$ & $19.93 \pm 0.55^{\mathrm{a}}$ & $45.65 \pm 1.58^{\mathrm{ab}}$ \\
T4 & $53.42 \pm 0.65^{\mathrm{a}}$ & $66.05 \pm 0.42^{\mathrm{a}}$ & $20.50 \pm 0.34^{\mathrm{a}}$ & $48.88 \pm 0.65^{\mathrm{a}}$ \\
T5 & $53.17 \pm 0.61^{\mathrm{a}}$ & $65.27 \pm 1.48^{\mathrm{a}}$ & $21.05 \pm 0.82^{\mathrm{a}}$ & $48.37 \pm 0.54^{\mathrm{a}}$ \\
T6 & $52.27 \pm 1.08^{\mathrm{a}}$ & $65.04 \pm 2.53^{\mathrm{a}}$ & $19.59 \pm 1.03^{\mathrm{a}}$ & $42.71 \pm 1.08^{\mathrm{b}}$ \\
T7 & $52.68 \pm 0.92^{\mathrm{a}}$ & $65.95 \pm 0.46^{\mathrm{a}}$ & $20.63 \pm 0.55^{\mathrm{a}}$ & $45.33 \pm 1.67^{\mathrm{ab}}$ \\
T8 & $52.90 \pm 0.83^{\mathrm{a}}$ & $64.54 \pm 0.65^{\mathrm{a}}$ & $22.20 \pm 1.03^{\mathrm{a}}$ & $48.37 \pm 0.56^{\mathrm{a}}$ \\
T9 & $51.17 \pm 0.89^{\mathrm{a}}$ & $64.75 \pm 1.65^{\mathrm{a}}$ & $21.33 \pm 1.67^{\mathrm{a}}$ & $48.54 \pm 1.66^{\mathrm{a}}$ \\
F test & $* *$ & $* *$ & $* *$ & $* *$ \\
CV \% & 2.81 & 3.54 & 7.32 & 4.24
\end{tabular}

Values are means \pm standard error of three replicates. Means followed by the same letter are not significantly different from each other at 5\% significant level according to Tukey's honestly significant difference test at 5\% significant level.

application enhanced the shelling $\%$ in groundnut. Application of full dose of NPK fertilizers with gypsum beyond $300 \mathrm{~kg} / \mathrm{ha}$ did not improve the pod and seed weights as well as shelling\% in groundnut. On the other hand, Prabhakaran et al. (1998) reported that application of 17:34:54 kg/ha NPK fertilizers $+500 \mathrm{~kg} / \mathrm{ha}$ gypsum +12.5 $\mathrm{kg} /$ ha micronutrient mixture increased the yield of groundnut. It may be probably due to the addition of micronutrients to the soil. In NPK fertilizers + 10 t/ha FYM + gypsum treatments, increasing gypsum level upto $450 \mathrm{~kg} / \mathrm{ha}$ remarkably enhanced the seed yield about $18 \%$ as compared to NPK fertilizers + 10 t/ha FYM treatment (T6).

\section{Plant biomass}

A significant effect on mean crop residue was noticed $(\mathrm{P}<0.01)$ between untreated and treated fertilizers (Table III). Crop residue included shoot and root weights but excluding shell weight which can be ignored. It ranged from $14.22 \mathrm{~g}$ (T1) to $22.20 \mathrm{~g}$ (T8). Gypsum treatment did not exhibit any remarkable impact on crop residue. On the other hand, average plant biomass was markedly varied $(\mathrm{P}<0.05)$ by the gypsum application (300-450 kg/ha) and its weight was about 48 g. No significant difference was showed between gypsum untreated and treated plants at $150 \mathrm{~kg} / \mathrm{ha}$ which had plant biomass within a range of 42-45 g. Positive effects on crop residue and plant biomass of groundnut were observed due to the gypsum application. Addition of FYM with NPK fertilizers improved physical, chemical and biological properties of soil for better plant growth (Deshmukh et al., 2005).
Pod yield

There was a remarkable variation $(\mathrm{P}<0.01)$ in an average pod yield among the treatments (Table IV). It was slightly influenced by the gypsum application with NPK fertilizers alone (T3-T5) or in combination with FYM (T7-T9). The highest pod yield (4204.44 kg/ha) was recorded in T4 (NPK fertilizers + gypsum at $300 \mathrm{~kg} / \mathrm{ha}$ ), which was statistically similar with the other gypsum treated plants. The pod yield increased considerably with increase of gypsum level from $150 \mathrm{~kg} / \mathrm{ha}$ to $450 \mathrm{~kg} / \mathrm{ha}$ in NPK fertilizers + FYM + Gypsum treatments. The lowest yield (1698.77 kg/ha) was noticed in T1 i.e. in absolute control. Gypsum provides calcium and sulfur for groundnut crop and sulfur is an important element for protein and oil synthesis (Rao et al., 2013). Groundnut yield increased with Zn, B and S application to soil (Chitdeshwari and Poongathai, 2003). Adequate quantities of macro and micro nutrients are necessary for obtaining better pod yield of groundnut.

\section{Seed yield}

In groundnut, seed yield enhanced significantly $(\mathrm{P}<0.01)$ with the application of fertilizers (Table IV). Treatment T4 (65:100:75 kg/ha NPK fertilizers $+300 \mathrm{~kg} /$ ha gypsum) gave highest seed yield $(2777.28 \mathrm{~kg} / \mathrm{ha})$ compared to the other treatments and the lowest value $(875.05 \mathrm{~kg} / \mathrm{ha})$ was recorded in $\mathrm{T} 1$. Treatment $\mathrm{T} 4$ showed significant effect $(\mathrm{P}<0.05)$ on seed yield as compared to T2 (65:100:75 kg/ha NPK fertilizers) which gave $2276.05 \mathrm{~kg} / \mathrm{ha}$. There was also a remarkable difference between T6 (30:50:37.5 kg/ha NPK fertilizers + 10 t/ha FYM) and T9 (3050:37.5 kg/ha NPK fertilizers +10 
Table IV. Pod yield, seed yield, and harvest index in each treatment.

\begin{tabular}{lccc}
\hline Treatments & Pod yield $(\mathrm{kg} / \mathrm{ha})$ & Seed yield $(\mathrm{kg} / \mathrm{ha})$ & HI \\
\hline T1 & $1698.77 \pm 71.22^{\mathrm{c}}$ & $875.05 \pm 51.36^{\mathrm{d}}$ & $23.04 \pm 0.38 \mathrm{~b}$ \\
T2 & $3551.11 \pm 99.08^{\mathrm{b}}$ & $2276.05 \pm 43.50^{\mathrm{bc}}$ & $35.11 \pm 1.00^{\mathrm{a}}$ \\
T3 & $3810.37 \pm 166.05^{\mathrm{ab}}$ & $2501.93 \pm 81.64^{\mathrm{abc}}$ & $36.99 \pm 0.10^{\mathrm{a}}$ \\
T4 & $4204.44 \pm 60.77^{\mathrm{a}}$ & $2777.28 \pm 49.94^{\mathrm{a}}$ & $38.35 \pm 0.20^{\mathrm{a}}$ \\
T5 & $4046.91 \pm 193.01^{\mathrm{ab}}$ & $2637.53 \pm 98.96^{\mathrm{ab}}$ & $36.79 \pm 0.98^{\mathrm{a}}$ \\
T6 & $3425.19 \pm 182.84^{\mathrm{b}}$ & $2219.75 \pm 62.75^{\mathrm{c}}$ & $35.13 \pm 1.35^{\mathrm{a}}$ \\
T7 & $3658.27 \pm 169.21^{\mathrm{ab}}$ & $2413.83 \pm 126.46^{\mathrm{bc}}$ & $35.91 \pm 0.55^{\mathrm{a}}$ \\
T8 & $3906.17 \pm 83.40^{\mathrm{ab}}$ & $2521.98 \pm 78.79^{\mathrm{abc}}$ & $35.08 \pm 1.43^{\mathrm{a}}$ \\
T9 & $4031.11 \pm 58.56^{\mathrm{ab}}$ & $2609.88 \pm 69.68^{\mathrm{ab}}$ & $36.31 \pm 0.42^{\mathrm{a}}$ \\
F test & $* *$ & $* *$ & $* *$ \\
CV \% & 5.98 & 5.49 & 4.19 \\
\hline
\end{tabular}

Values are means \pm standard error of three replicates. Means followed by the same letter are not significantly different from each other at 5\% significant level according to Tukey's honestly significant difference test at 5\% significant level.

t/ha FYM $+450 \mathrm{~kg} / \mathrm{ha}$ gypsum). Seed yields in T6 and T9 were $2219.75 \mathrm{~kg} / \mathrm{ha}$ and $2609.88 \mathrm{~kg} / \mathrm{ha}$, respectively. Furthermore, it was noted that no significant variation was observed in seed yield between T2 and T6.

In reduced dose $(30: 50: 37.5 \mathrm{~kg} / \mathrm{ha})$ of NPK fertilizers +10 t/ha FYM + gypsum treatments, higher dose (450 kg/ha) of gypsum treatment (T9) gave $2609.88 \mathrm{~kg} / \mathrm{ha}$ seed yield followed by $300 \mathrm{~kg} / \mathrm{ha}$ gypsum application (T8) which had $2521.98 \mathrm{~kg} / \mathrm{ha}$ seed yield and both values were statically similar. Gashti et al. (2012) mentioned that highest pod and seed yield were achieved from $90 \mathrm{~kg}$ calcium through gypsum. Calcium and sulphur are significant soil nutrients for groundnut crop and sulphur deficiency is common on sandy textured soils (Sigh et al., 1993). As a result, combined fertilization leads to balanced nutrient supply and improved soil fertility over application of inorganic or organic source alone (Ayeni and Adetunji, 2010).

\section{Harvest index}

All fertilized treatments significantly increased $(\mathrm{P}<0.05)$ pod and seed numbers, 100 seed weight, pod and seed weights, shelling $\%$, plant biomass, pod yield, seed yield and harvest index compared to unfertilized treatment where the type of soil at the site is sandy regosol which has relatively low organic carbon, total nitrogen and potash. Yield and yield components were increased with the addition of gypsum to all the NPK fertilized plots. Highest harvest index (HI) was $38.35 \%$ in NPK fertilizers with $300 \mathrm{~kg} /$ ha gypsum treatment (T4) while absolute control (T1) gave significantly $(\mathrm{P}<0.05)$ least value of $\mathrm{HI}$ from the fertilizers treated plants in which
HI ranged from $35.11 \%$ to $38.35 \%$ (Table IV). Further, it was observed that harvest index was statically similar in the fertilized treatments.

\section{Conclusion}

The results reveal that significant increase in seed yield $(2777.28 \mathrm{~kg} / \mathrm{ha})$ was noted in full dose $(65: 100: 75 \mathrm{~kg} / \mathrm{ha})$ of NPK fertilizers with $300 \mathrm{~kg} / \mathrm{ha}$ gypsum treatment than full dose of NPK fertilizers alone (typical control) which had $2276.05 \mathrm{~kg} / \mathrm{ha}$ seed yield. Application of reduced NPK fertilizers with FYM $+300 \mathrm{~kg} / \mathrm{ha}$ gypsum resulted to 2521.98 $\mathrm{kg} / \mathrm{ha}$ seed yield which was statically similar to that of the typical control. All gypsum treatments had also positive effect on yield components and $300 \mathrm{~kg} / \mathrm{ha}$ gypsum with full dose of NPK fertilizers or reduced dose of NPK fertilizers + 10 t/ha FYM were the optimum level for obtaining the higher pod and seed yields of groundnuts.

\section{Acknowledgement}

This research was carried out through the financial support under National Agricultural Research Plan (NARP) 20112015 from Sri Lanka Council for Agricultural Research Policy (SLCARP), Sri Lanka.

\section{References}

Ahmad N and Rahim M (2007), Evaluation of promising groundnut (Arachis hypogaea L.) varieties for yield and other characters, J. Agri. Res. 45(3): 185-189. 
Alvarez C, Taboada MA, Boem FHG and Bono A (2009), Topsoil properties as affected by tillage systems in the rolling Pampa region of Argentina, Soil Sci. Soc. Am. J. 73: $1242-1251$

Atasie VN, Akinhanmi TF and Ojiodu CC (2009), Proximate analysis and physico-chemical properties of groundnut (Arachis hypogeae L.), Pak. J. Nutr. 8(2): 194-197.

Ayeni LS and Adetunji MT (2010), Integrated application of poultry manure and mineral fertilizer on soil chemical properties, nutrient uptake, yield and growth components of maize, Nat. Sci. 8(1): 60-67.

Busscher WJ, Novak JM, Evans DE and Watts DW (2010), Influence of pecan biochar on physical properties of a Norfolk loamy sand, Soil Sci.175: 10-14.

Chitdeshwari T and Poongathai S (2003), Yield of groundnut and nutrient uptake as influenced by $\mathrm{Zn}, \mathrm{B}$, and S, Agri. Sci. Dig. 23: 263-265.

Compaore E, Catton P and Taonda JBS (2011), Effect of continuous mineral and organic fertilizer inputs and plowing on groundnut yield and soil fertility and groundnut sorghum rotation in Central Burkina Faso, In: (eds.) Innovation as key to green revolution in Africa. Bationo A, Waswa B, Okeyo JM, Mainaand F and Kihara JM, Springer, Netherlands, pp 597-603.

Deshmukh KK, Khatik SK and Dubey DP (2005), Effect of Integrated use of inorganic, organic and biofertilizers on production, Nutrient availability of plateau and Satpura hills, J. Soils Crops 15(1): 21-25.

Gashti AH, Vishekaei MNS and Hosseinzadeh MH (2012), Effect of Potassium and Calcium Application on Yield, Yield Components and Qualitative Characteristics of Peanut (Arachis hypogaea L.) in Guilan Province, Iran, World Appl. Sci. 16(4): 540-546.

Hamza MAM and Abd-Elhady ESE (2010), Effect of organic and inorganic fertilization on vegetative growth and volatile oil of marjoram (Majoranahortensis L.) plant, J. Soil Sci. Agri. Eng. 1(8): 839-851.

Mokhtariniya S and Siadat SA (2011), The study of using zeolite integrated with sheep manure before composting in reducing the consumption of chemical fertilizer in corn cultivation in light textured soils in Khuzestan, Iran, Am. J. Sci. Res. 32: 90-97.

Munda GC, Patel DP and Islam M (2004), Effect of macro and micronutrients on growth and yield of groundnut, Ann. Plant Physiol. 18 (1): 9-12.

Prabhakaran NK, Lourduraj AC, Madhiyazhagan R, Venkitasamy R and Sridharan CS (1998), Fertiliser management in Rabi/summer groundnut, Madras Agri. J. 85(10-12): 685-686.

Rao KT, Rao AU and Sekhar D (2013), Effect of Sources and Levels of Sulphur on Groundnut, J. Acad. Indus. Res. 2(5): 268-270.

Rao SS and Shaktawat MS (2005), Effect of organic manure, phosphorus and gypsum on nutrient uptake in groundnut, Agropedology 15(2): 100-106.

Reddy SR (2006), Agronomy of field crops. 2nd Ed. Kalyani publisher, New Delhi, India.

Shah H, Khan MA, Azeem T, Majid A and Mehmood A (2012), The Impact of gypsum application on groundnut yield in rainfed Pothwar: An Economic Perspective, Lahore J. Econ. 17(1): 83-100.

Singh B, Singh B and Khandelwal RB (1993), Response of groundnuts to phosphaticfertiliser and their mode of application with and without gypsum on yield, quality and P uptake, J. Indian Soc. Soil Sci. 41:383-384.

Thilakarathna SMCR, Kirthisinghe JP, Gunathilaka BL and Dissanayaka DMPV (2014), Effect of calcium on yield and visual quality of groundnut, Int. Res. Sessions, Sri Lanka (Arachishypogaeal.), In: Proc. the Peradeniya Univ. Vol. 18, 4-5 July 2014, Peradeniya University, Sri Lanka. p 561.

Veeramani P and Subrahmaniyan K (2011), Nutrient management for Sustainable groundnut Productivity in India - a Review, Int. J. Eng. Sci. Tech. 3(11): 81388153.

Received: 08 December2015; Revised: 12 April 2016; Accepted: 24 April 2016. 